\title{
長野オリンピック冬季競技大会入賞メダルの製作
}

衣 畑 良 則*

\section{Making of Winner's Medals for the X VIII Olympic Winter Games, Nagano 1998}

Yoshinori KINUHATA*

Key Words : Medals, Cloisonné, Japanning, Traditional Handicraft

造幣局では, これまで 1964 年に開催された第 18 回東京オリンピック夏季大会の入賞メダルおよび 1972 年の第 11 回札幌オリンピック冬季大会の入賞メダルを造幣技術の粋を集めて製作してきた。平 成 10 年 2 月に開催された第 18 回長野オリンピック冬季大会の入賞メダルについても, これを担当し たところである。そこで,このメダルについての仕様,完成に至るまでの経緯などについて以下に紹介 する。

1. これまでの冬季オリンピックにおける入 賞メダル

オリンピックの入賞メダルについては，オリン ピック憲章にその条件が定められているが，冬季 オリンピックのメダルでは, オリンピック憲章に 「オリンピアード競技大会用に使用されたものと 異なっていなければならない」と定められている ことから,これまで, 各大会ごとに工夫をこらし たメダルが製作されてきた。

1992 年の第 16 回アルベールビル大会では, 金, 銀, 銅以外の素材として水晶ガラスが使用され, 大会の大きな話題となった。また, 1994 年の第 17 回 リレハンメル大会では, ジャンプ会場建設地から切 り出された岩石がメダルの素材として使用された。

\section{2. 長野オリンピック入賞メダル製作にあ} たっての基本的考え方

*大蔵省造幣局（广530-0043 大阪府大阪市北区天満 1-1-79） Mint Bureau, Ministry of Finance, Japan (1-1-79, Tenma, Kita-ku, Osaka-shi, Osaka 530-0043)
今回の長野オリンピック入賞メダル製作にあ たっての(財)長野オリンピック冬季競技大会組織委 員会(NAOC)の考え方は，以下のとおりであっ た。

(1)オリンピック憲章に定められる金属の部分と， 長野オリンピック独自の素材，技法を組み合わ せたメダルとする。

(2)世界の人々が，日本らしさを連想できるような メダルとする。また，日本の人々が長野らしさ を連想できるようなメダルとする。

(3)後世においても恒久的な価值を有するメダルと する。

(4)選手の宝となるにふさわしい, 美しいメダルと する。

(5)温度, 湿度の変化や衝撃に対し, 耐久性のある メダルとする。

(参考)

入賞メダルに関するオリンピック憲章項目 (抜粋)

・ 1 位および 2 位の選手に与えられるメダルは， 純度 1000 分の 925 以上の銀を使用する。

・ 1 位の選手に与えられるメダルは，6グラム 
以上の純金でめつきを施す。

・ 3 位の選手に与えられるメダルは, 銅を使用 する。

- 直径 $60 \mathrm{~mm}$ 以上, 厚さ $3 \mathrm{~mm}$ 以上とする。

・取り外し可能な鎖，またはりボンに取り付け， 選手の首にかけられるようになっていること。

・受賞の対象となった競技種目を明記すること。

\section{3. 日本らしさ, 長野らしさの具体的表現}

基本的な考え方に基づき，NAOC を中心に具 体的に検討がなされた。特に，アルベールビルの 水晶ガラス, リレハンメルの岩石に代わる素材で 日本らしさと長野らしさを現わすものについて検 討し, その結果, 符絵の技法を取り入れた漆 (木 曽漆器)を使用することがNAOCにより決定さ れた。

すなわち, (1)漆器は, 英語で japanもしくは Japanese Lacqer とも呼ばれていることからわか るように, 日本の漆器は世界的に名高く, 木曾漆 器は, 長野を代表する特産品である。(2)漆器の芸 術的価值を高める蒔絵の技法は, 平安前期 ( 9 世 紀)に始まる我が国独自の漆工芸技法である。(3) 蒔絵の分野を含む漆工からは, 重要無形文化財保 持者 (人間国宝)を多数排出している。などの理由 によるものである。
このことから，長野オリンピック入賞メダルの コンセプトである「日本らしさ」と「長野らし さ」を表現するにふさわしいものとして，漆工芸 を採用し，これに造幣局の七主焼の技術を加える ことにより，後世においても恒久的な価值を有し， 選手の宝となるにふさわしい美しい入賞メダルを 製作することとなった。

\section{4. デザイン}

これを受け，長野オリンピック入賞メダルのデ ザインは，日本らしさ，長野らしさを表現するこ とがそのポイントとされた。長野オリンピックの エンブレム自身が長野オリンピックのイメージを 象徵しているため, 基本的には華美なデザインは 避け，エンブレム(長野オリンピックのシンボル マーク)を中心にシンプルなデザインとすること とされた。また，色彩を取り入れることにより， 長野オリンピックの独自性が表現された。

表面は，オリーブをあしらったリング状の金属 製の外枠の中に「朝日」を蒔絵により表現され (漆部品)，その上の円い金属部品に，造幣局の高 度な七宝技術によりカラフルなエンブレムが表現 された。漆面に接着された金属文字は，精密金属 加工技術によって形成されたものである。

裏面は，金属製の外枠の中に，信州の山々の朝

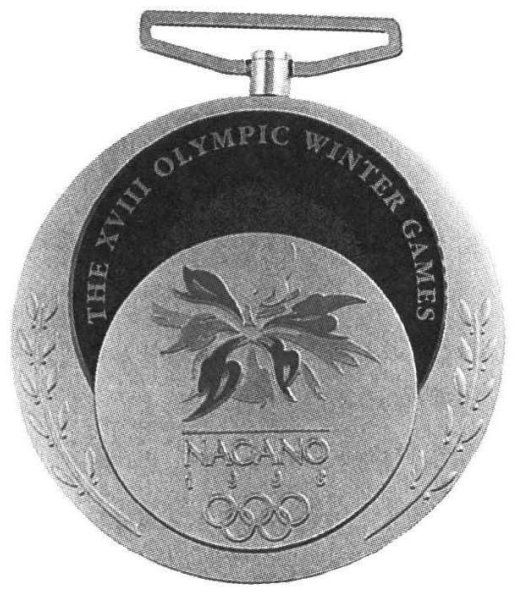

表

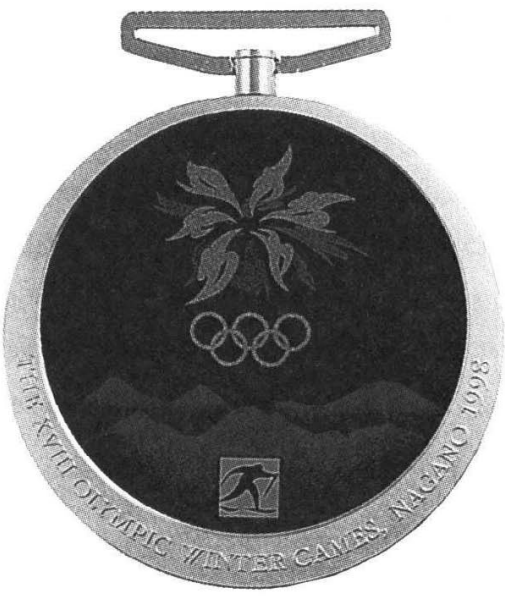

裏

図 1 入賞メダルの表裏 
焼けと，その山並みの上にエンブレムが咲き誇っ ている様子を蒔絵により表現した円い漆部分が大 きく取り入れられている。競技種目は，精密金属 加工技術によって形成されたピクトグラム（絵文 字)を円い漆部品の下部に接着することにより示 された。

これにより，一つのメダルの中に日本の伝統的 技法(漆) と，西洋の伝統的技法 (七宝)，および， 先端技術である精密金属加工技術の 3 つが融合さ れ，これらの各分野の最高位の技術がひとつのメ ダルの中にバランスよく配置されており，非常に 品格のあるものとなった。(図 1 参照)

\section{5. 長野オリンピック入賞メダルの製作技法}

長野オリンピック入賞メダルの製作技法および 製作担当は以下のとおりである。

(1)長野オリンピック入賞メダルは, 外枠部品(表, 裏), 七宝焼部品(エンブレム), 漆部品(表,

裏)で構成し，蒔絵の技法，七宝焼，精密金属 加工技術により文様をつける。

(2)七宝焼部品は，勲章の製作で培った技術を，ま た外枠部品のレリーフおよび文字の刻印は貨幣 製造で培った技術を応用し，大蔵省造幣局が製 作する。

(3)漆部品は，ひとつひとつを木曽の漆職人が手作 りで製作し，財団法人木曽地域地場産業振興セ ンター「木曽くらしの工芸館」がこの業務を取 りまとめる。

(4)漆面に配置する文字および競技種目を示すピク トグラムは，時計の文字盤などに使用される技 術を応用した精密金属加工によるものとし，セ イコーエプソン株式会社が製作する。

(5)そして, 最終のメダル組立工程は, 高度の工芸 技術を有する造幣局が担当する。

\section{6. 入賞メダルの製作}

長野オリンピック入賞メダルは, 外枠部品(表, 裏), 七宝焼部品(エンブレム), 漆部品(表, 裏) および中子の 6 個の部品と吊り金具から構成され
ている。

この中で，漆部品以外はすべて造幣局が製作を 担当した。その中でも入賞メダルを映えあるもの とした七宝焼部品(エンブレム)の製作にまつわる ことと組立作業の方法を中心に説明する。

\section{1 七宝とは}

七宝という言葉は, 本来仏教用語で金, 銀, 瑠 璃, 珊瑚, 琥珀, 真珠, 瑪瑙など 7 つ宝物に似 た色光沢を持つ美しいガラスのことである。東洋 美術史においては秦, 漢時代頃から, 西洋美術史 では古代エジプトから, 各地各様の複雑で精細な 技法が発達してきている。

日本では，白鳳，奈良時代から製作が知られ， 七宝焼最古の正倉院御物の瑠璃鈿背十二“稜 鏡を はじめ, 平安時代の宇治平等院鳳凰堂の屝金具や 江戸時代初期の桂離宮, 西本願寺の襖引手等に古 い作例がある。

七宝技術は，勲章にも取り入れられ，昭和の始 めから造幣局が勲章製作を開始したことにより， 技術としてさらに練磨された。一般の七宝製品の 下地は望銅が多いのに対して，勲章の下地は銀で あることから, 勲章には, 銀の化学的, 物理的性 質に合った特別の粙薬が使われている。

七宝の美しさの秘密は, 普通の板ガラスには使 われていない鉛分(正確には酸化鉛)にある。鉛は, 釉薬の原料である珪宕を溶かしたり, 銀や銅の上 に焼き付ける際にその溶融温度を下げる働きをす るだけでなく，できあがったガラスの光沢，透光 性，色調を著しくよいものにしてくれる。これは， 鉛のないシリカガラスに比べて鉛ガラスの届折率 が高いためである。

\section{2 エンブレムの色に適した七宝釉薬}

無色透明の釉薬の原料は，ガラスの基になる珪 石と溶剤の化合物であり，これに乳濁剤，着色剤 などの薬品を加えることにより，目的の色を持っ た釉薬を作ることができる。

しかし，これらの薬品を調合する時のちょっと したさじ加減で，実にさまざまな色合いが生まれ る。さらに，焼き付ける温度や時間によっても表 面の色艶が変化する。

長野オリンピック入賞メダルの場合, 長野オリ ンピックの象徵であるエンブレムに使用する七宝 
色数は, 6 色(赤, オレンジ, 黄, 緑, 青, 紫) と 決定されており，これを忠実に表現するためには， 七宝独特の色合いとは異なる蛍光色のような色合 いを出す必要があった。ところが，勲章に使用し ている釉薬は, 勲章独特の深みのある色を使って いるため, 入賞メダル用の釉薬としては適さな かった。さらに，入賞メダルは，部品ごとに単独 の色のみで焼き付けを行っている勲章とは異なり， 6 色同時に焼き付けることが必要であったが, 勲 章に使用している釉薬は, それぞれ融点に違いが あり，このままでは使用できないことが判明した。

そこで，造幣局の釉薬製造担当者が，勲章の製 作で培った技術を生かし，まず，エンブレムの七 宝釉薬作りの基礎となる胎 (土台となるガラス状 のもの)を開発し，使用することとした。

次に, この胎に着色剂等の薬品を加えて色見本 を作り，焼き付けテストを繰り返し，NAOCの 希望どおりの色合いとなる釉薬として, 銀メダル 用の 6 色すべてと銅メダル用の 3 色(赤，黄，青） を新しく開発し，エンブレムの仕様に合う色を出 すことに成功した。

特に, 銀メダル用の赤色釉薬は, 鉛分が災いし て暗い赤になりがちな上に，着色剤に含まれるイ オウ分と銀が反応して黒ずみやすいという泣き所 を克服してでき上がったものである。

したがって, 長野オリンピック入賞メダルのエ ンブレムの製作には，釉薬を作る技術だけでなく メダルに焼き付ける技術にも造幣局の職人芸が活 かされているといえる。

\section{3 七宝作業担当者の製作を終えての感想}

勲章の場合には, 七宝の色ごとに部品が分かれ ているので, たとえば, 白色釉の軟化温度が赤色 釉の軟化温度より $50^{\circ} \mathrm{C}$ 高くても, それぞれの発 色が最もよい温度と時間で焼き付けることができ る。

長野オリンピック入賞メダルの場合は, 同じ部 品に 6 色もの釉薬を同時に焼き付けるため, 釉薬 の温度にバラツキがあると，ある色はきれいに焼 き上がっても他の色の発色が悪いという大きな壁 にぶつかり, 新釉薬を開発する必要があった。

また，金メダルは，七宝を焼き付けた後に金 めつきを行うので, 酸性のめつき液につけても七
宝が溶け出さないように化学的に強い釉薬でなけ ればならないというやっかいな制約もあり，入賞 メダルに適した釉薬を作るのに大変苦労した。

七宝の焼き付け作業は，まず，すりつぶした釉 薬に水と少量の糊を加えて泥状にする。次に，そ れを銀板や銅板の模様の中に盛りつけて水分を蒸 発させ, 最後に, 電気炉に入れ, 約 $850^{\circ} \mathrm{C} て ゙$ 焼き 付けをする。この作業を $2 \sim 3$ 回繰り返し，表面 を研磨して仕上げ焼きをして完成品となる。

ところが，エンブレムのデザインは，模様の先 に細い部分があり，ここに七宝を盛り付ける際に 水の表面張力のため, 釉薬が入りにくく, 盛り付 けに苦労した。また，銅メダルについては，焼き 付け時にこの先端部に赤い皮膜ができ，酸化する という銅地金の宿命ともいうべき現象があり，こ の細かい部分の酸化皮膜を取り除く作業に苦労を した。

\section{4 組立作業}

入賞メダルは，図 2 に示すように 6 個の部品を 以下の手順により組立てることにより完成する。

まず，外枠表部に七宝焼部品をネジおよび接着 剂で固定したあと，七宝焼部品の裏面に漆部品表 部をネジおよび接着剤で固定する。これに中努をを 組み込み，上部をネジおよび接着剂で固定するこ とによりメダルの表部が組みあがる。

次に, 外枠裏部に漆部品裏部を接着剤で固定す ることによりメダルの裏部が組みあがる。

上記により組み立てた表部に裏部を嵌め込み接 着剂で固定し，最後に綬を取り付けた吊り金具を メダル上部に取り付け，飾りネジで固定すること により完成品となる。

\section{5 長野オリンピック入賞メダルの仕様}

長野オリンピック入賞メダルの仕様は表 1 のと おりである。

\section{7.おわりに}

2 月 7 日から 22 日まで 16 日間にわたり開催さ れた長野オリンピック冬季大会が無事終わり，日 本が獲得したメダル総数は, 10 個 (金メダル 5 個, 銀メダル 1 個，銅メダル 4 個) と冬季オリンピッ ク史上最多となった。造幣局が製作した入賞メダ 


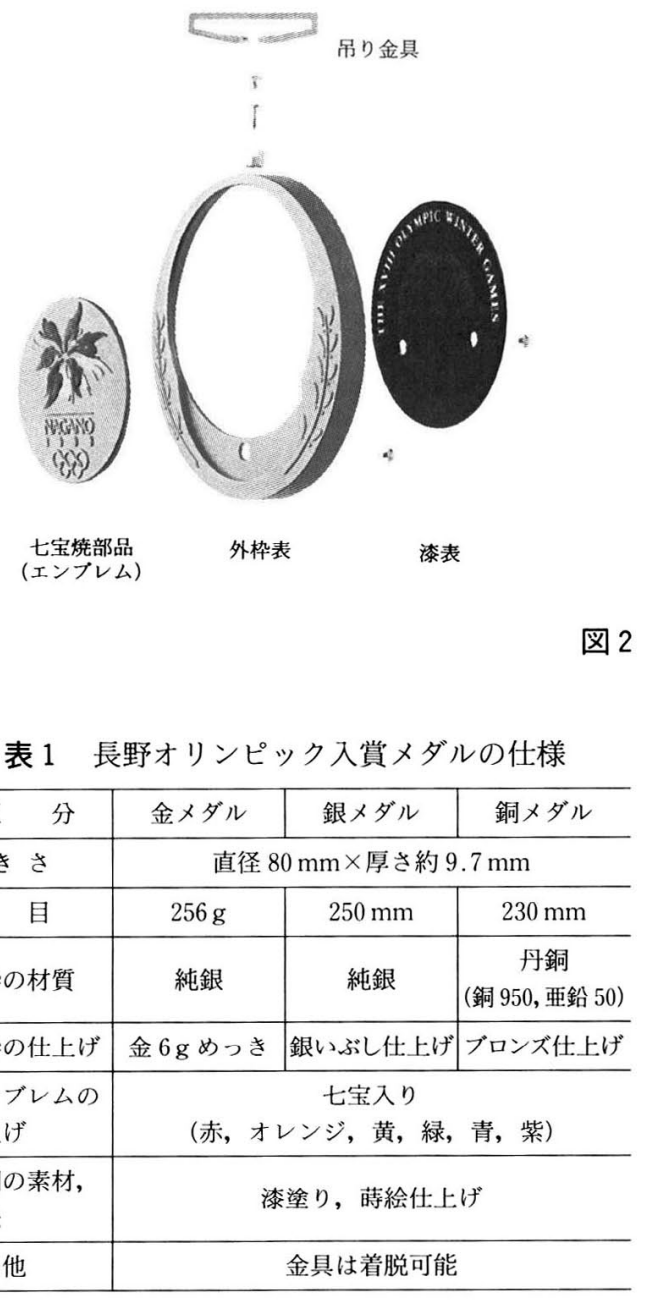

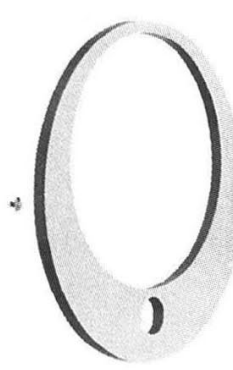

中子

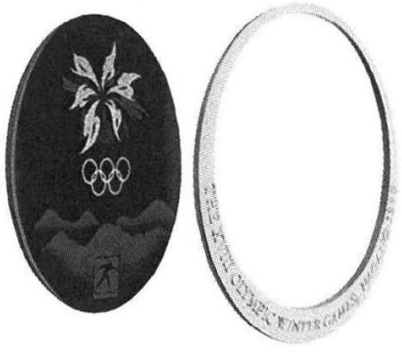

㴚裹

外枠敫

図 2 組立図

ルを選手が誇らしげに掲げている姿を見て，製作 に携わったことを職員一同喜んでいる。

今回の長野オリンピック入賞メダル製作で得た 知見を今後の造幣事業に活かしていきたいと考え ている。

なお，長野オリンピック冬季大会に引き続き開 催された長野パラリンピック冬季競技大会の入賞 メダルについては, 金属単体で作られていること から，デザインから製作，組立てまですべて造幣 局が担当した。

* 本稿は, 平成 10 年 4 月に発刊された「造幣局技報

第 1 号」に掲載されたものを転載したものである。 